\title{
NATURAL HISTORY OF THREE HYDROPSYCHIDAE (TRICHOPTERA, INSECTA) IN A “CERRADO” STREAM FROM NORTHEASTERN SÃO PAULO, BRAZIL
}

\author{
Leandro Gonçalves Oliveira ${ }^{1}$ \\ Claudio Gilberto Froehlich ${ }^{2}$
}

\begin{abstract}
The faunal composition of the Hydropsychidae (Trichoptera) of Pedregulho Stream is presented. Feeding habits of larvae and behavioural aspects of both larvae and adults are described.

KEY WORDS. Trichoptera, Hydropsychidae, Smicridea, Leptonema, biology, larvae, behaviour
\end{abstract}

Biological studies on the Brazilian aquatic insect fauna are still incipient. This is particularly valid for the Trichoptera. Some references on the subject are MÜLLER (1880), SCHUBART (1946), VANZOLINI (1964), SCHROEDER-ARAUJO \& Cipolli (1986), Oliveira $(1988,1991)$ and NEssimian (1995).

A general presentation on the Trichoptera collected in Córrego do Pedregulho, São Paulo, and a discussion of the role of abiotic factors is found in OLIVEIRA \& FROEHLICH (in press). In this paper aspects of the natural history of Hydropsychidae, in particular of the genera Smicridea and Leptonema, are presented.

The cosmopolitan Hydropsychidae is one of the largest Trichoptera families in running waters (HAUER \& STANFord 1981; DeutsCH 1984). Most larvae are collectors-filterers (WIGGINS 1977; MACKAY 1984); they can be recognized by the numerous abdominal gills and by the sclerotized thoracic terga (MERRITT \& CUMMINS 1979; FLINT 1982; ROLDÁN 1990). They build fixed tubular retreats with small stones and plant fragments, with the opening directed towards the current (WIGGINS 1977).

Smicridea Mclachlan, 1871, is a very common hydropsychid genus and the sole representative of the subfamily Hydropsychinae in South America (FLINT 1974). It has been the subject of taxonomic studies in Argentina (FLINT 1980, 1982, 1983), Chile (FLINT 1989) and Brazil (FLINT 1978, 1983).

Leptonema Guérin, 1843, belonging to the Macronematinae, was revised by FLINT et al. (1987), who considered this genus as a very important component of stream biotas.

1) Departamento de Biologia Geral, Instituto de Ciências Biológicas, Universidade Federal de Goiás. Caixa Postal 131, 74001-970 Goiânia, Goiás, Brasil.

2) Departamento de Biologia, Faculdade de Filosofia, Ciências e Letras, Universidade de São Paulo. 14040-901 Ribeiräo Preto, São Paulo, Brasil. 


\section{MATERIAL AND METHODS}

This study was made in Córrego do Pedregulho, a fourth-order stream situated in northeastern São Paulo State, with coordinates $20^{\circ} 13^{\prime}$ 'S and $47^{\circ} 26^{\prime} \mathrm{W}$, at an altitude of ca. $700 \mathrm{~m}$. Details on the study area, collection methods, abiotic factcr measurements, and head width measurements of Leptonema and Smicridea are found in OLIVEIRA \& FroeHLich (in press).

\section{LARVAL FEEDING HABITS AND COLLECTING NETS}

For a qualitative assessment of the chief food items of Smicridea and Leptonema, 5-10 larvae of each genus and month (when possible) were dissected under a stereomicroscope. The whole digestive tracts were removed to a glass slide with water, shredded, and examined under a microscope. Contents were separated into diatoms, green algae, Cyanobacteria, arthropod fragments, plant fragments and detritus. The algae were identified with the keys of JOLY (1963) and BICUDO \& BICUDO (1970). Meshes of two filtering nets, one of each genus, were measured.

\section{RESULTS}

\section{FAUNAL COMPOSITION}

Three hydropsychid genera were collected: Leptonema, Macronema Pictet, 1836 and Smicridea; a total of 5935 individuals were collected, 3299 (55.6\%) larvae, $82(1.4 \%)$ pupae and $2554(43.0 \%)$ adults (Tab. I). For specific identification, material was sent to Dr. O.S. Flint Jr., but as only adults could be identified, larvae and pupae were studied at the generic level.

Table I. Monthly and total numbers of larvae, pupae and adults of the hydropsychid genera Leptonema, Macronema and Smicridea collected in Córrego do Pedregulho, São Paulo.

\begin{tabular}{|c|c|c|c|c|c|c|c|c|c|c|c|c|c|}
\hline Month & Jan & Feb & Mar & Apr & May & Jun & Jul & Aug & Sep & Oct & Nov & Dec & Total \\
\hline \multicolumn{14}{|l|}{ Leptonema } \\
\hline Larvae & 12 & 34 & 45 & 204 & 218 & 143 & 51 & 33 & 30 & 40 & 225 & 8 & 1043 \\
\hline Pupae & - & - & 1 & - & 1 & 6 & 4 & 12 & 4 & 2 & 3 & - & 33 \\
\hline Adults & 5 & 15 & 4 & 22 & - & - & 8 & 4 & 32 & 42 & 20 & 14 & 166 \\
\hline \multicolumn{14}{|l|}{ Macronema } \\
\hline Adults & - & - & - & 1 & - & 1 & - & - & - & - & - & 1 & 3 \\
\hline \multicolumn{14}{|l|}{ Smicridea } \\
\hline Larvae & 5 & 18 & 204 & 157 & 378 & 192 & 91 & 228 & 464 & 133 & 379 & 7 & 2256 \\
\hline Pupae & - & - & - & - & - & 8 & 8 & 2 & 13 & 10 & 8 & - & 49 \\
\hline Adults & 58 & 205 & 135 & 158 & 6 & 1 & 1 & 112 & 447 & 1021 & 175 & 66 & 2385 \\
\hline \multicolumn{14}{|l|}{ Total } \\
\hline Larvae & 17 & 52 & 249 & 361 & 596 & 335 & 142 & 261 & 494 & 173 & 604 & 15 & 3299 \\
\hline Pupae & - & - & 1 & - & 1 & 14 & 12 & 14 & 17 & 12 & 11 & - & 82 \\
\hline Adults & 63 & 220 & 139 & 181 & 6 & 2 & 9 & 116 & 479 & 1063 & 195 & 81 & 2554 \\
\hline Total & 80 & 272 & 389 & 542 & 603 & 351 & 163 & 391 & 990 & 1248 & 810 & 96 & 5935 \\
\hline
\end{tabular}

\section{1) Larvae}

Of the 3299 larvae collected, 1043 (31.6\%) belonged to Leptonema and 2256 (68.4\%) to Smicridea. The genus Leptonema had its lowest densities during the rainiest months, viz. 12 larvae in January, 34 in February and 8 in December; the largest number was 225 larvae in November. The genus Smicridea presented a 
similar picture, with 5 larvae in January, 18 in February and 7 in December, whereas the largest number, 464, occurred in September (Tab. I). No larvae of Macronema were collected.

\section{2) Pupae}

Eighty two pupae were collected, 33 (40\%) belonging to Leptonema and 49 $(60 \%)$ to Smicridea. The largest number of Leptonema pupae, 12, was collected in August. No pupae were collected in January, February, April and December. Smicridea had the largest number, 13 pupae, in September; no pupae were collected from January to May and in December. No pupae of Macronema were collected (Tab. I).

\section{3) Adults}

Two thousand, five hundred and fifty four adults were collected, $166(6.5 \%)$ belonging to the genus Leptonema, $3(0.1 \%)$ to Macronema and $2385(94.4 \%)$ to Smicridea (Tab. I). October had the largest number of Leptonema collected (42 individuals); no adults were collected in May and June. The Macronema adults were collected one each in April, June and December. Smicridea also had the largest number in October (1021 individuals), whereas the lowest numbers were collected in June and July (1 individual each).

Based on representative adult samples, the following species were identified by Dr. Flint: Leptonema viridianum Navás, 1916, L. pallidum Guérin, 1843, Macronema immaculatum Mosely, 1934, Smicridea nigripennis Banks, 1920, S. dentifera Flint, 1983, S. coronata Flint, 1980, S. vermiculata Flint, 1978, and S. unguiculata Flint, 1983.

One hundred and eight Leptonema adults collected ( $65 \%$ of the total) belonged to $L$. viridianum, of which $64(59.2 \%)$ were males and $44(40.8 \%)$ were females. L. pallidum had 58 adults collected (35\% of the total), of which $32(55.2 \%)$ were males and $26(44.8 \%)$ were females (Tab. II).

The genus Macronema was represented by one male of $M$. immaculatum in April, one female in December and by another female of an unidentified species in June.

Most Smicridea species are difficult to separate. In order to avoid identification errors, only $S$. coronata was distinguished against the remaining species (Tab. II). With 265 specimens, S. coronata comprised $11.2 \%$ of the total, of which 132 $(49.8 \%)$ were males and $133(50.2 \%)$ were females. They were most abundant in February (100 individuals) but no adults were collected in May and June. Smicridea spp. were most abundant in October (1004 individuals) and none was collected in July. $67 \%$ of Smicridea spp. were males and $33 \%$ females.

\section{LARVAL GUT CONTENTS AND COLLECTING NETS}

Larval gut contents were assessed qualitatively (Tab. III). Both Leptonema and Smicridea had diatoms as their most frequent food item. Green algae as well as insect fragments (mayflies, occasionally chironomids) were also common, especially in Leptonema. In February, in the latter genus, higher plant leaf fragments were found. 
The mesh size of a collecting net of a third instar Leptonema larva was 250 by $360 \mu \mathrm{m}$. That of a Smicridea larva was 60 by $68 \mu \mathrm{m}$.

Table II. Monthly and total numbers of adult males (M) and females (F) of the species of the genera Leptonema, Macronema and Smicridea (Hydropsychidae) collected by the Córrego do Pedregulho, São Paulo.

\begin{tabular}{|c|c|c|c|c|c|c|c|c|c|c|c|c|c|}
\hline Month & Jan & Feb & Mar & Apr & May & Jun & Jul & Aug & Sep & Oct & Nov & Dec & Total \\
\hline \multicolumn{14}{|l|}{ Leptonema } \\
\hline L. viridianum $(\mathrm{M})$ & 2 & 5 & - & 6 & - & - & 3 & 1 & 11 & 13 & 12 & 11 & 64 \\
\hline L. viridianum $(F)$ & 1 & 1 & 4 & 9 & - & - & 4 & 1 & 7 & 9 & 5 & 3 & 44 \\
\hline L. pallidum (M) & - & 4 & - & 2 & - & - & - & - & 9 & 16 & 1 & - & 32 \\
\hline L. pallidum (F) & 2 & 5 & - & 5 & - & - & 1 & 2 & 5 & 4 & 2 & - & 26 \\
\hline Total & 5 & 15 & 4 & 22 & - & - & 8 & 4 & 32 & 42 & 20 & 14 & 166 \\
\hline \multicolumn{14}{|l|}{ Macronema } \\
\hline M. immaculatum (M) & - & - & - & 1 & - & - & - & - & - & - & - & - & 1 \\
\hline M. immaculatum (F) & - & - & - & - & - & - & - & - & - & - & - & 1 & 1 \\
\hline Macronema sp. (F) & - & - & - & - & - & 1 & - & - & - & - & - & - & 1 \\
\hline Total & - & - & - & 1 & - & 1 & - & - & - & - & - & 1 & 3 \\
\hline \multicolumn{14}{|l|}{ Smicridea } \\
\hline S. coronata (M) & 11 & 33 & 7 & 49 & - & - & 1 & 1 & 12 & 10 & 2 & 6 & 132 \\
\hline S. coronata (F) & 4 & 67 & 11 & 14 & - & - & - & 4 & 21 & 7 & 3 & 2 & 133 \\
\hline Smicridea sp. (M) & 17 & 44 & 70 & 51 & 4 & - & - & 41 & 327 & 712 & 117 & 38 & 1421 \\
\hline Smicridea sp. (F) & 26 & 61 & 47 & 44 & 2 & 1 & - & 66 & 87 & 292 & 53 & 20 & 699 \\
\hline Total & 58 & 205 & 135 & 158 & 6 & 1 & 1 & 112 & 447 & 1021 & 175 & 66 & 2385 \\
\hline
\end{tabular}

Table III. Food items found in the digestive tracts of larvae of the genera Leptonema and Smicridea (Hydropsychidae) collected in Córrego do Pedregulho, São Paulo. (D) Diatoms, (C) green algae, (Ci) blue-green algae, (Fi) insect fragments, (Fv) plant fragments, (R) detritus.

\begin{tabular}{cll}
\hline Month & Leptonema & Smicridea \\
\hline Jan & $\mathrm{D}+\mathrm{C}$ & $\mathrm{D}$ \\
Feb & $\mathrm{D}+\mathrm{Fi}+\mathrm{Fv}$ & $\mathrm{D}+\mathrm{Fi}$ \\
Mar & $\mathrm{D}+\mathrm{C}+\mathrm{Fi}$ & $\mathrm{D}+\mathrm{C}+\mathrm{Fi}$ \\
Apr & $\mathrm{D}+\mathrm{C}+\mathrm{Fi}$ & $\mathrm{D}+\mathrm{C}+\mathrm{Fi}$ \\
May & $\mathrm{D}+\mathrm{C}+\mathrm{Ci}+\mathrm{Fi}$ & $\mathrm{D}+\mathrm{Fi}$ \\
Jun & $\mathrm{D}+\mathrm{C}+\mathrm{R}$ & $\mathrm{D}+\mathrm{C}+\mathrm{Fi}$ \\
Jul & $\mathrm{D}+\mathrm{Fi}$ & $\mathrm{D}$ \\
Aug & $\mathrm{D}+\mathrm{Fi}$ & $\mathrm{D}$ \\
Sep & $\mathrm{D}+\mathrm{C}+\mathrm{Fi}$ & $\mathrm{D}$ \\
Oct & $\mathrm{D}+\mathrm{C}+\mathrm{Fi}$ & $\mathrm{D}+\mathrm{C}$ \\
Nov & $\mathrm{D}+\mathrm{C}+\mathrm{Fi}$ & $\mathrm{D}+\mathrm{C}$ \\
Dec & $\mathrm{D}+\mathrm{C}$ & $\mathrm{D}$ \\
\hline
\end{tabular}

\section{BEHAVIOURAL ASPECTS}

\section{1) Larvae}

Larvae of Leptonema were observed both in the field and in the laboratory. In the field, during the day, they showed little activity. When touched, they crawled backwards into their retreats and soon began the stridulation behaviour, which 
consists of rubbing the anterior femora against the ventral, striated head surface. If disturbed within their retreats, after a few seconds they abandoned them and the substrate, swam with dorso-ventral undulations of the body, and entered the drift. No observations were made on Smicridea larvae on account of their small size.

In the laboratory the larvae were put in aquaria with small stone fragments and coarse sand as well as plant fragments as substrate. Most remained at the bottom, under stones or larger objects, but a few Smicridea settled at mid-height, close to the stream of air bubbles from the air pump. They began soon to build their nets; if these were in part mechanically damaged, they were promptly repaired. Ventilation behaviour - abdominal undulations to increase gas exchanges - were observed in the larvae of both genera.

\section{2) Adults}

Observations on adults were made only in the field. Females of Leptonema were observed, in places where water turbulence was reduced; flying against the current and touching the water surface with the abdominal apex. Both Leptonema and Smicridea were observed in copula under leaves of the riparian vegetation males and females stayed in opposite directions, connected only by their terminalia.

A peculiar characteristic is their strongly hydrophobic surface. Some netted individuals were put into vials with water and even after strong shaking they kept themselves dry.

In an observation made in October, they were active all day $(24 \mathrm{~h})$ long, but more so early in the morning and late in the afternoon.

\section{DISCUSSION}

A discussion of the possible roles of abiotic factors on the Trichoptera fauna in Córrego do Pedregulho is found in Oliveira \& Froenlich (in press). In reference to life cycles, the fact that all sizes of larvae are practically found the year round indicates that Smicridea and Leptonema are multivoltine (l.c.). The hydropsychid fauna of the riffles studied is well diversified, with two species in Leptonema, two in Macronema and five in Smicridea.

\section{LARVAL FOOD COMPOSITION}

According to the feeding categories of CuMMINS \& KLUG (1979), the net-spinning hydropsychid larvae are basically collectors-filterers. HYNES (1970) considered them to be omnivores. WIGGINS (1977) and MERRITT \& CUMMINS (1979) state that they are predominantly collectors, and in part predators. WALLACE (1975) verified that larvae of the smaller instars were chiefly herbivorous, while larger ones (4th and 5th instars) were mostly carnivorous. FULLER \& MACKAY $(1980,1981)$ found as the main food items for three species of Hydropsyche Pictet, 1834, diatoms, animal fragments and detritus.

The chief food items of Leptonema and Smicridea from the State Park of Campos do Jordão, São Paulo, were diatoms, plant fragments, detritus and remains of small aquatic invertebrates (unpublishing observations).

This study shows that the main food item of the hydropsychid larvae of 
Córrego do Pedregulho are diatoms, with green algae and insect fragments also being important besides a few minor items (Tab. III). These results support WIGGINS \& MACKAY (1978), who consider the family Hydropsychidae as generalists.

ALSTAD (1980) verified in several hydropsychid species that there is a direct relation between head width and net mesh size. Mesh sizes of third instar Leptonema larvae and heads measured here were similar to those found by that author for the same instar larvae.

\section{BEHAVIOURAL ASPECTS}

JOHNSTONE (1964), studying hydropsychid larvae, observed the stridulation behaviour of Hydropsyche fulvipes Curtis, 1834, H. contubernalis MaLachlan, 1865 and $H$. pellucidula Curtis, 1834 . He suggested two purposes for this behaviour: to ward off potential predators or as a territoriality mechanism among larvae. The behaviour observed here in disturbed larvae support the first suggestion.

WIGGINS (1977) mentioned the ventilating behaviour of caddisfly larvae when subjected to respiratory stress. The same behaviour was observed here in Leptonema and Smicridea larvae maintained in aquaria.

Another interesting larval activity is the spinning of the filtering nets. SATTLER (1962, 1963), studying the spinning behaviour in Hydropsyche and Macronema, observed also the repairing ability of damaged nets. The spinning and repairing of nets was observed here in Smicridea larvae kept in aquaria.

The mating position in Trichoptera, with the pair remaining in opposite directions, is well-known (RIEK 1970).

The observed behaviour of females touching the water surface in gently flowing stretches could indicate oviposition. However, according to DEUTSCH (1984), who studied the egg-laying habits of Cheumatopsyche speciosa Banks, 1904 and Hydropsyche phalerata Hagen, 1861, the hydropsychids submerge to lay their eggs, and air bubbles retained by the folded wings act as a physical gill and prevents wetting the body. This waterproofing was observed in Leptonema females collected at the Boracéia Biological Station, São Paulo, which, when put into plastic vials half-filled with water, laid their eggs as described above.

\section{REFERENCES}

ALSTAD, D.N. 1980. Comparative biology of the common Utah Hydropsychidae (Trichoptera). Amer. Midl. Nat. 103 (1): 164-169.

Bicudo, C.E.M. \& R.M.T. Bicudo. 1970. Algas de Águas Continentais Brasileiras. São Paulo, FUNBEC, 228p.

Cummins, K.W. \& M.J. KLUG. 1979. Feeding ecology of stream invertebrates. Ann. Rev. Ecol. Syst. 10: 147-172.

DEUTSCH, W.G. 1984. Oviposition of Hydropsychidae (Trichoptera) in a large river. Can. J. Zool. 62: 1988-1994.

FLINT JR., O.S. 1974. Studies of neotropical caddisflies XVII: The genus Smicridea from North and Central America (Trichoptera:Hydropsychidae). Smithson.

Contr. Zool. 167: 1-65. 
1978. Studies of neotropical caddisflies XXII: Hydropsychidae of the Amazon Basin (Trichoptera). Amazoniana 6 (3): 373-421.

1980. Studies on neotropical caddisflies XXVI: new species from Argentina (Trichoptera). Rev. Soc. Ent. Argentina 39 (1-2): 137-142.

- 1982. Trichoptera of the area Platense. Biol. Acuática 2: 1-70.

1983. Studies of neotropical caddisflies, XXXIII: new species from Austral South America (Trichoptera). Smithson. Contr. Zool. 377: 1-100.

1989. Studies of neotropical caddisflies XXXIX: the genus Smicridea in the Chilean subregion (Trichoptera:Hydropsychidae). Smithson. Contr. Zool. 472: 1-45.

FLINT JR., O.S.; J.F. MCALPINE \& H.H. Ross. 1987. A revision of the genus Leptonema Guerin (Trichoptera: Hydropsychidae: Macronematinae). Smithson. Contr. Zool. 450: 1-193.

FUlLER, R.L. \& R.J. MACKAY. 1980. Feeding ecology of three species of Hydropsyche (Trichoptera: Hydropsychidae) in southern Ontario. Can. J. Zool. 58: 2239-2251.

1981. Effects of food quality on the growth of three Hydropsyche species (Trichoptera: Hydropsychidae). Can. J. Zool. 59: 1133-1140.

HAUER, F.R. \& J.A. STANFORD. 1981. Larval specialization and phenotypic variation in Arctopsyche grandis (Trichoptera: Hydropsychidae). Ecology 62 (3): 645-653.

HYNES, H.B.N. 1970. The Ecology of Running Waters. Liverpool, Liverpool Univ. Press, XXIV+555p.

JoHnstonE, G.W. 1964. Stridulation by larval Hydropsychidae (Trichoptera). Proc. R. ent. Soc. Lond. (A) 39 (10-12): 146-150.

Joly, A.B. 1963. Gêneros de Algas de Água Doce da Cidade de São Paulo e Arredores. Secretaria de Agricultura do Estado de São Paulo. 187p.

MACKAY, R.J. 1984. Life history patterns of Hydropsyche bronta and H. morosa (Trichoptera: Hydropsychidae) in summer-warm rivers of southern Ontario. Can. J. Zool. 62: 271-275.

MERRITT, R.W. \& K.W. CUMmins. 1979. An Introduction to the Aquatic Insects of North America. Iowa, Ed. Kendall/Hunt Publishing Company, $2^{\text {nd }}$ Ed., $441 \mathrm{p}$.

MÜLlER, F. 1880. Sobre as casas construídas pelas larvas de insectos Trichopteros da Província de Santa Catharina. Arch. Mus. Nac. Rio de Janeiro 3 (1878): 99-134, 209-214.

NESSIMIAN, J.L. 1995. Composição da fauna de invertebrados bentônicos em um brejo entre dunas no litoral do Estado do Rio de Janeiro, Brasil. Acta Limnol. Bras. 7: 41-59.

OliveIRA, L.G. 1988. Estudos de comunidades de insetos bentônicos de um rio de montanha em Campos do Jordão, SP. Monograph, not published, Faculdade de Filosofia, Ciências e Letras de Ribeirão Preto, Universidade de São Paulo, São Paulo, V+28p.

1991. Estudo da fauna de Trichoptera do Córrego do Pedregulho, 
Pedregulho-SP, com especial referência a família Hydropsychidae. Master Dissertation, not published, Faculdade de Filosofia, Ciências e Letras de Ribeirão Preto, Universidade de São Paulo, São Paulo, VIII+84p.

OliveirA, L.G. \& C.G. FroeHLich (in press). The Trichoptera (Insecta) fauna of a "cerrado" stream insoutheastern Brazil. Naturalia.

RIEK, E.F. 1970. Trichoptera, p.741-764. In: CSIRO (Ed.). The Insects of Australia. Melbourne, Melbourne University Press, XIII+1029p.

ROLDÁN, G. 1990. Guia para el estudio de los macroinvertebrados acuáticos del Departamento de Antioquia. Medelin, Fondo Fen Colombia Colciencias, Universidad de Antioquia, XI+217p.

SATTLER, W. 1962. Die "Meisterweber". Umschau 7: 205-208. 1963. Über den Körperbau, die Ökologie und Ethologie der Larve und Puppe von Macronema Pict. (Hydropsychidae). Arch. Hydrobiol 59 (1): 26-60. SCHROEDER-ARAuJo, L.T. \& M.N. Cipolli. 1986. Organismos bentônicos como indicadores da qualidade de água de rios do Parque Estadual de Campos do Jordão, SP. B. Inst. Pesca 12 (3): 77-83.

SCHUBART, O. 1946. Observações sobre a produtividade biológica das águas de Monte Alegre. A fauna aquática da região. Bol. Ind. Anim. São Paulo, n.s., 8 (1-2): 22-54.

VANZOLINI, P.E. 1964. História Natural de Organismos Aquáticos do Brasil. São Paulo, FAPESP, 452p.

WALLACE, J.B. 1975. The larval retreat and food of Arctopsyche, with phylogenetic notes on feeding adaptations in Hydropsychidae larvae (Trichoptera). Ann. Entomol. Soc. Amer. 68 (1): 167-173.

Wiggins, G.B. 1977. Larvae of the North American Caddisfly Genera (Trichoptera). Toronto, University of Toronto Press, XI+401p.

WigGINS, G.B. \& R.J. MACKAY. 1978. Some relationships between systematics and trophic ecology in Neartic aquatic insects, with special reference to Trichoptera. Ecology 59 (6): 1211-1220.

Recebido em 08.V.1996; aceito em 20.XI.1996. 